\title{
Incidences of anthropogenic pressure on the degradation of the scrub of the western Algerian region (Tlemcen, case of Djebel Felloucene): qualitative and quantitative aspects
}

\author{
Rachid Dahmani I,*, Abdessamed Merzouk² \& Sid Ahmed Aouadj' \\ ${ }^{1}$ Laboratory of Ecology and Management of Natural Ecosystems (LEGEN 13), Abou Bakr Belkaid University, Tlemcen, \\ Algeria \\ *Corresponding author, email: ecologie.rachid@gmail.com
}

\begin{abstract}
The scrub of Djebel de Fellaoucene is one of the forests of the mounts of the Traras (western of Algeria) that undergoes enormous variations which vary according to the regressive or progressive dynamics under climatic and anthropogenic pressures in semi-arid zones. These landscapes are in fact a mosaic in which several types of matorrals such as scrubland or scrub overlap, determined by multiple factors: the local climate (drought, climatic aridity, etc.), the importance of human activities; overgrazing is also a major limiting factor. This current study provides a qualitative and quantitative assessment of the anthropogenic pressure exerted in this area. The methodology adopted in this study is that of Le Houerou (1969) and Montoya (1983), which is based on the calculation of the annual needs of the herd in forage units, the estimation of the food production potential, the overgrazing coefficient and in addition the anthropogenic pressure index. The result of the forage balance in the forest rangelands of the study area has a forage deficit (overload) of -7,962,360 UF (a sylvopastoral imbalance), the overgrazing coefficient is (91\%) and the anthropogenic pressure index is very high (26). The quantification of the impact of anthropogenic action and overgrazing on the forest formations effects makes it possible to establish a trajectory of the cumulative anthropogenic impacts on this area in order to develop restoration strategies and more effective means of protection.
\end{abstract}

KEY WORDS Anthropogenic pressure index; Djebel Fellaoucene; overgrazing; scrub; qualitative; quantitative.

Received 10.02.2021; accepted 27.07.2021; published online 30.09.2021

\section{INTRODUCTION}

The forest and pre-forest ecosystems of the Mediterranean area have undergone regressive changes due to multiple biogeographical influences and various human pressures over the millennia. The current state of Mediterranean forest ecosystems is in fact the result of a combination of edapho-climatic and anthropo-zoogonic factors, in particular: clearing, overgrazing, cutting, etc. (Quézel, 1985-1995; Kadik, 1987; Benabdeli, 1996; Sespedes, 2014; Aouadj et al., 2020a-g).
Algeria, like the Mediterranean, is as a whole subject to significant anthropogenic pressure and the overexploitation of forests and matorrals, well beyond their capacity for regeneration, leading to an almost total disappearance of woody plants (deforestation and dematoralisation) which are replaced by perennial herbs (steppization) and by annual herbs (therophytization) (Babali, 2014; Aouadj, 2021).

Until the 18th century, the inhabitant of Algeria used the forests as a rangeland. In front of the abundance of pastures, herds multiplied and the need for pasture increased. Thus the clearing 
took on a remarkable pace and the terrain extended. In 1941 the Oran region had 125,000 permanent forest users, plus 90,000 temporary ones. The population on which pastoral life was imposed was difficult to dissociate from the forest. This permanent relationship has had for a long time, now and soon, the phenomena of clearing, grazing, right of use, cutting offenses, and fires as consequences (Benbadeli, 1996).

The rate of degradation and the multiplication of factors mean that any form of woody vegetation, whatever its stage of regression, continues to be destroyed and nothing is spared; the last ramparts of natural fight against the phenomena of steppization and desertification are seriously threatened. One by one we will try to analyze these degrading factors (human action and overgrazing). The appreciation of the possible pastoral load by plant formation and the actual load observed make it possible to understand the concept of overload (pastoral deficit) and pressure leading to degradation. These elements first require an evaluation of the forage possibilities offered. El Hamrouni (1978) established a relationship between rainfall, average production in forage units per hectare and possible pastoral load in the pine grove of the semi-arid stage in Tunisia. Aouadj et al. (2020) are trying to quantify these anthropogenic actions at the level of the Doui Thabet-Western of Algeria area (which is close to our study region). They obtained the following result: index of anthropogenic action is order 28 (unitless), overgrazing coefficient is $92.30 \%$ and forage deficit is $-8,952,450$ UF. In the region of Tlemcen, like all of Algeria, the forest routes and the delimbing of the forest plant cover constitute the main source of fodder for pastoral breeding during periods of drought.

The practice of trekking in the forest refers to traditional concepts of animal husbandry and to a collective use of pastoral forest resources.

Unfortunately, there are only few scientific works on the quantification of anthropogenic actions in Algeria. We cite only 3 studies: one by Benabdeli (1996) and another by Aouadj et al. (2020) and Aouadj (2021). The objective of this work is to quantify the impact of anthropogenic action and overgrazing on the forest formations of the NorthWest Algerian zone (Tlemcen: case of the scrub of Djebel Felloucene) on the basis of indices and coefficients developed by certain authors: Montaya (1983) and Le Houerou (1969).

\section{MATERIAL AND METHODS}

\section{Study area}

The study area is located in the western part of north-western Algeria (Oranie) in the Traras massifs, "the scrub of Djebel Felloucene"; between $\left(35^{\circ} 05^{\prime} 44.74^{\prime \prime}\right.$ and $34^{\circ} 94^{\prime} 61.06^{\prime \prime} \mathrm{N}-001^{\circ}$ $61^{\prime} .30 .60^{\prime \prime}$ and $001^{\circ} 72^{\prime} .53 .72^{\prime \prime} \mathrm{W}$ ) at an altitude of $270 \mathrm{~m}$ to $1136 \mathrm{~m}$ asl with an area from 6259 ha. It consists of three forest masses: "Fellaoucene, Ain Kebira, Ain Fettah" (Fig. 1).

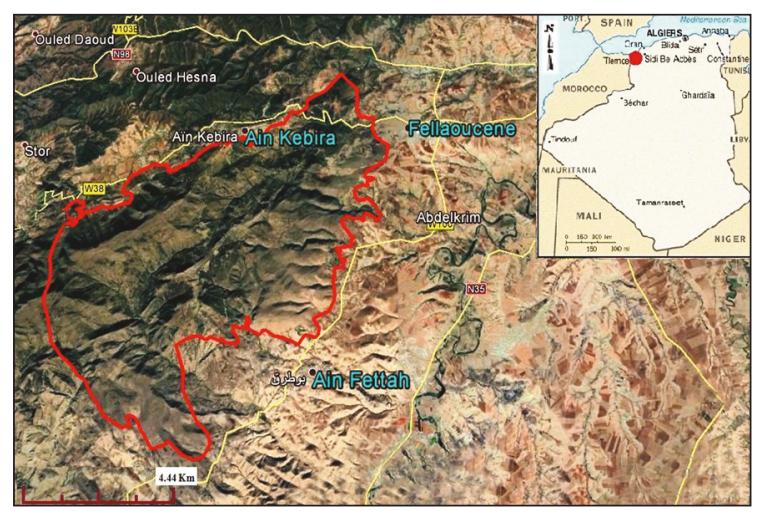

Figure 1. Study area (from Google Earth, 2021 modified).

This zone of the thermo-Mediterranean level in a temperate and warm semi-arid bioclimate. Climatic characterization of Mediterranean type, characterized by average annual precipitations of 400 to $600 \mathrm{~mm}$ with a seasonal rainfall regime of the type: Winter $>$ Spring $>$ Autumn $>$ Summer. The average annual temperature is $18.73{ }^{\circ} \mathrm{C}$ with a "m" of 5 ${ }^{\circ} \mathrm{C}$ and "M" of $30{ }^{\circ} \mathrm{C}$.

The ridges of this massif are made up of sandstone interspersed with blue limestone from the Upper Jurassic period giving abrupt reliefs, resting on Oxfordian schists and clays, which give regular slopes, and on hard Liasic limestones, again giving abrupt reliefs (Durand, 1954).

The vegetation is characterized by a floristic diversity representative of the thermo-xerophilic groups of Orania dominated by Thuja, Pistacia lentiscus and scrub.

\section{Methods}

To assess the impact of forest rangelands in the scrub of Djebel Fellaoucene, our investigations focused on measuring, on the one hand, the annual 
needs of the herd in fodder units, fodder production potential, the fodder deficit, the overgrazing coefficient and the anthropogenic pressure index. Indeed, this task was essential to identify indicators of degradation of rangelands and forests and to be able to present synthetic data for the entire study area.

\section{Pastoral potential of the forest}

The evaluation of the fodder production in UF (fodder unit) of the different species of the enumerated forest was estimated by referring to the standards presented by Le Houérou (1969) (Table 1).

\begin{tabular}{|l|c|c|}
\hline \multicolumn{1}{|c|}{ Taxa } & $\begin{array}{c}\text { Production in UF (UF/ha/year) } \\
\text { (Houérou, 1969) }\end{array}$ & $\begin{array}{c}\text { Average (UF) } \\
\text { (Present study) }\end{array}$ \\
\hline Olea europea & 40 & 20 \\
\hline Pinus halepensis & $25-100$ & 50 \\
\hline Quercus ilex & 300 & 150 \\
\hline Tetraclinis articulata & 40 & 20 \\
\hline Pistacia lentiscus & 40 & \\
\hline
\end{tabular}

Table 1. Average production in UF of the species.

For the determination of the needs of the herd in UF, one can use standards which were developed by Le Houerou in 1969 and given in Table 2.

\begin{tabular}{|c|c|}
\hline Livestock & $\begin{array}{c}\text { UF requirement (UF/ year and per } \\
\text { head }\end{array}$ \\
\hline Sheep & 400 \\
\hline Cattle & 1200 \\
\hline Goats & 350 \\
\hline
\end{tabular}

Table 2. Livestock requirement in UF by type of animal (Le Houérou, 1969).

The real load and the equilibrium load can be determined as follows (Le Houérou, 1969):

The real load $(\mathrm{Cr})=$ total livestock requirement in UF / per UGB requirement (UF of a large livestock).

We have (Houérou, 1969):

- 1 cattle represents $1 \mathrm{UGB}$

- 3 sheep represent 1 UGB

- 4 goats represent $1 \mathrm{UGB}$

Equilibrium load $=$ this is the total fodder production in UF / over the UF requirements of a large livestock.
The overgrazing coefficient can be determined as follows. It is expressed in percent of the equilibrium load (Le Houérou, 1969):

$$
\mathrm{S}=100 *(1-\mathrm{Ce} / \mathrm{Cr})
$$

S: Coefficient of overgrazing.

Ce: Balance load.

Cr: Actual load.

The method was adopted in Spain by Montoya (1983), and this only by determining constants K for each type of livestock according to its weight and the displacement in the cork oak forests to assess the Buffer radius or concentric radius of the pasture animals. To determine the pressure index we included, in addition to $\mathrm{K}$, the number of inhabitants per douar and the distance separating them from the study plots. To calculate this index, we made the sum of each type of livestock by multiplying it by its corresponding coefficient $\mathrm{K}$, the total number of inhabitants and the distance separating the douars from the plots. This index is calculated for the whole of each series and is given by the following equation:

$\mathrm{IPA}=[((\mathrm{NHd}+\mathrm{k}($ Number of cattle $)+\mathrm{k}($ Number of sheep) $+\mathrm{k}($ Number of goats) $\left.\left.) / \mathrm{D}^{2}\right) * \mathrm{Sz}\right] * 1000$

With:

IPA: anthropogenic pressure index

NHd: number of inhabitants by agglomeration: 23,131 (RGPH, 2019).

$\mathrm{K}$ : herd pressure coefficient (3.7 for cattle, 1.7 for sheep and 1.9 for goats)

$\mathrm{D}$ : distance separating the agglomeration from the forest calculated as follows: $\sqrt{ }(\mathrm{X} 1-\mathrm{X} 2)+(\mathrm{Y} 1$ - Y2) Where: $\mathrm{X} 1$ and $\mathrm{Y} 1$ are the real coordinates of the plot (forest) and $\mathrm{X} 2$ and $\mathrm{Y} 2$ are the theoretical coordinates of the plot.

So: $\mathrm{D}=0.4$ and $\mathrm{D}^{2}=0.10$

Sz: Total area of the pasture zone in $\mathrm{m}^{2}$ simulated to a circle whose radius is the distance from the douar to the plot $($ Radius $=100 \mathrm{~m})$ with $\mathrm{S}$ circle $=3.14 * \mathrm{r}^{2}$ $\mathrm{S}$ circle $=7900 \mathrm{~m}^{2}$.

In this regard, we have established 05 pressure index classes as shown in Table 3.

\begin{tabular}{|c|c|}
\hline Anthropogenic pressure index class & Class qualifier \\
\hline $0-5$ & Weak \\
\hline $5-10$ & Medium \\
\hline $10-15$ & Strong \\
\hline $15-20$ & Strong enough \\
\hline$>20$ & Very strong \\
\hline
\end{tabular}

Table 3. Anthropogenic pressure index classes (Montoya, 1983). 


\section{RESULTS}

In terms of numbers, the herd is largely dominated by sheep in the study area. Indeed, the average number of sheep registered in the study area is 16,864 compared to 1,553 goats and only 645 cattle (DSA, 2019). The average number of UPBs in the study area is around 21,000 UPB (Table 4).

\begin{tabular}{|c|c|}
\hline Livestock & 2009 to 2019 \\
\hline Sheep & 16864 \\
\hline Cattle & 675 \\
\hline Goats & 1553 \\
\hline
\end{tabular}

Table 4. Evolution of livestock numbers between 2009 and 2019.

The annual needs of the herd amount to $8,952,450$ fodder units. The fodder potential available in the forest rangelands of the study area is evaluated overall at 6,824,000 fodder units per hectare and per year. Indeed, Tables 5 and 6 below present the existing potential and the gaps in question.

\begin{tabular}{|c|c|c|c|c|}
\hline \multirow{4}{*}{\begin{tabular}{c}
\multirow{4}{*}{$\begin{array}{c}\text { Study } \\
\text { area }\end{array}$} \\
\cline { 2 - 4 }
\end{tabular}} & Livestock & Effective & $\begin{array}{c}\text { UF / year } \\
\text { and per head }\end{array}$ & $\begin{array}{c}\text { Fodder requirements } \\
\text { UF / year }\end{array}$ \\
\cline { 2 - 5 } & Sheep & 16864 & 400 & 6745600 \\
\cline { 2 - 5 } & Cattle & 675 & 1200 & 810000 \\
\cline { 2 - 5 } & Goats & 1553 & 350 & 543550 \\
\cline { 2 - 5 } & Total & $\mathbf{1 9 0 9 2}$ & $/$ & $\mathbf{8 0 9 9 1 5 0}$ \\
\hline
\end{tabular}

Table 5. Assessment of the annual needs of the livestock in forage units.

\begin{tabular}{|c|l|c|c|c|}
\hline \multirow{5}{*}{$\begin{array}{c}\text { Taxa } \\
\text { Study } \\
\text { area }\end{array}$} & $\begin{array}{c}\text { Area (Ha) } \\
\text { (CF, 2019) }\end{array}$ & $\begin{array}{c}\text { Potential in } \\
\text { UF / ha / year } \\
\text { (Average) }\end{array}$ & $\begin{array}{c}\text { Fodder } \\
\text { potential UF / } \\
\text { year }\end{array}$ \\
\cline { 2 - 5 } & Olea europea & 428 & 20 UF/ha/year & 8560 \\
\cline { 2 - 5 } & Pimus halepensis & 8 & $50 \mathrm{UF} / \mathrm{ha} /$ year & 400 \\
\cline { 2 - 5 } & Quercus ilex & 547 & $150 \mathrm{UF} / \mathrm{ha} /$ year & 82050 \\
\cline { 2 - 5 } & $\begin{array}{c}\text { Tetraclinis } \\
\text { articulata }\end{array}$ & 1041 & $20 \mathrm{UF} / \mathrm{h} /$ year & 20820 \\
\cline { 2 - 5 } & Pistacia lentiscus & 1248 & 20 UF/ha/year & 24960 \\
\cline { 2 - 5 } & \multicolumn{3}{|c}{ Total } & 136790 \\
\hline
\end{tabular}

Table 6. Evaluation of the fodder potential offered by the forest in the area.

The results of the forage balance, overgrazing coefficient and anthropogenic pressure index of the study area are shown in Table 7.

\begin{tabular}{|l|c|}
\hline \multicolumn{1}{|c|}{ Indicators } & Study area \\
\hline Fodder needs (UF / Year) (UF/An) & 8099150 \\
\hline Forestry potential in UF & 136790 \\
\hline Fodder deficit UF & -7962360 \\
\hline Coefficient of overgrazing (S) & $91 \%$ \\
\hline Anthropogenic pressure index & 26 (without unit) \\
\hline
\end{tabular}

Table 7. Fodder balance, overgrazing coefficient and anthropogenic pressure index of the study area.

\section{DISCUSSION}

In the study area (Djebel Fellaoucene,) which interests us, the herd is made up of cattle, sheep and goats. The dominant species in terms of number is the ovine species ( 16,864 heads) which is widely present everywhere and is likely to enhance many woody species. The goat is in 2 nd place with a number of 1,553 heads allowing to use difficult and poor areas. It is an excellent processor, a valuable supplier of animal protein for farmers in poor regions to own a cow (Aouadj et al., 2020; Aouadj, 2021). The goat species withstands harsh conditions, gives milk daily and often makes two kids a year and can thus be considered "the cow of the poor". If cattle are also present everywhere, however, they represent a much lower number (675 heads). The herd is therefore made up of the two largely dominant species (goats and sheep).

In fact, breeding is starting to gain momentum in the study area. The weaknesses of the production systems in the area have favored the orientation of households towards the livestock activity.

Herd management is generally extensive and relies primarily on natural and forest ranges. This calendar shows that cattle graze practically 9 out of 12 months in the forest, or about 230 days per year. Indeed, once the grassland resources have been exhausted, the shepherds are forced to prune trees and shrubs in order to meet a large part of the herds' fodder needs. A very close result is reported by Aouadj et al. (2020) and Aouadj (2021) in the forest of Doui Thabet (Saida, Western of Algeria).

In the study area, the annual livestock needs amount to 8,099,150 fodder units. The needs of sheep represent the major part $(90 \%)$. These requirements are of the order of $6,745,600 \mathrm{UF}$, followed by those of cattle with 810,000 UF and finally goats with only 543,550 UF. These needs are mainly drawn from forest rangelands, the potential of which remains below existing capacities, which contrib- 
utes to overgrazing and strong pastoral pressure.

The fodder potential available in the forest rangelands of the study area is evaluated overall at 136,790 fodder units per hectare and per year. Analysis of the results obtained shows that the fodder potential of forest areas does not meet the food needs of the livestock in the same terms. The needs are much higher than the fodder supply. (The comparison of the needs of the livestock and the quantities of fodder available in the study area shows an average annual fodder deficit of -7,962,360 UF).

The forage deficit and the high coefficient of overgrazing calculated can only give an idea of the current state of forest rangelands, but they confirm the enormous pressure exerted on our ecosystem.

For our study area, the anthropogenic pressure index is very high (26) and the overgrazing coefficient is very high $(91 \%)$ because this forest contains many inhabitants and livestock. It is a meeting place for people and animals who frequent it from all directions and exert considerable pressure there. The pressure of the inhabitants on this forest is very strong and results in clearing, cutting of trees and shrubs and repeated fires.

Forest rangelands are subject to strong anthropozoogenic pressure which continues to degrade them and expose them to the effects of desertification/rat extermination. The insufficiency of technical frameworks specialized in research and extension in the pastoral field constitutes an obstacle to the development of this sector. However, with a view to safeguarding this heritage and combating desertification at the country level, it is important to improve the plant cover through defenses, to readjust the load in view of the capacity of production, the sowing of rangelands with high productivity species, the establishment of fodder shrub plantations, the practice of mineral manure and the complementarity between pastoral production of rangelands and the production of fodder on the perimeters irrigated. The establishment of a pastoral strategy, based on legislation or its strict application when it exists concerning the protection of rangelands and natural resources, appears to be of particular urgency and is urgently needed.

The analysis of the indicators developed confirms the observation that one can a priori draw while prospecting in the forest, as it turned out that the study area is grossly suffering from very pronounced overgrazing. Indeed, the silvo-pastoral balance is seriously compromised: the overall recorded overgrazing rate is of the order of $91 \%$. It is similar to other Mediterranean forests such as the case of the Tabarka cork forest in Tunisia where the overgrazing rate was $69.3 \%$ for Chaäbane (1984), $77 \%$ for El Hamrouni (1992) and 83\% for Nsibi (2005) , $68 \%$ for the Maamora forest in Morocco (Laaribya et al., 2012) and Aouadj et al. (2020) and Aouadj (2021) for the Doui Thabet forest (Saida, Western of Algeria).

\section{CONCLUSIONS}

The results obtained following the study and analysis of silvo-pastoral data, as well as the current fodder balance and the high coefficient of overgrazing, can only inform us about a grazing pressure to which the Fellaoucene zone is subjected. This phenomenon will undoubtedly be able, if it continues, to disrupt an entire ecosystem, which obliges us to put forward proposals for the rehabilitation and restoration of degraded pastoral potential. These proposals must take into account the ecological context, the region and the aspirations of the rural population living in the forest environment. Thus, we must seek to involve this population in decision-making especially when it comes to touching their only source of income, the livestock. The proposals must consider, among other things, the economic reality of the country.

\section{REFERENCES}

Aouadj S.A., 2021. Impact des techniques de restauration écologique sur la dynamique des écosystèmes dégradés des monts de Saida: cas des forêts de Doui Thabet (Ouest Algérie). Thesis of Doctorat, University of Tlemcen, Algeria, $167 \mathrm{pp}$.

Aouadj S.A., Hasnaoui O. \& Nasrallah Y., 2020. Ethnobotanical Approach and Floristic Inventory of Medicinal Plants in the Doui Thabet Region (Saida-Western Algeria). PhytoChem \& BioSub Journal, 14: 92-104. https://doi.org/10.163.pcbsj/2020.14.-1-92

Aouadj S.A., Nasrallah Y. \& Hasnaoui O., 2020. Note on the orchids of mounts of Saida (Saida Western Algeria) in the context of the restoration. Ecology, Environment and Conservation, 26: 37-45.

Aouadj S.A., Nasrallah Y. \& Hasnaoui O., 2020. Ecological characterization and evaluation of the floristic potential of the forest of Doui Thabet (Saida Western Algeria) in the context of the restoration. 
Ecology, Environment and Conservation, 26: 266-278.

Aouadj S.A., Nasrallah Y. \& Hasnaoui O., 2020. Regional phytogeographic analysis of the flora of the Mounts of Saida (Algeria): evaluation-restoration report. Biodiversity Journal, 11: 25-34. https://doi.org/10.31396/Biodiv.Jour.2020.11.1.25.34

Aouadj S.A., Nasrallah Y., Hasnaoui O. \& Khatir H., 2020. Impacts of anthropogenic pressure on the degradation of the forest of Doui Thabet (Saida, Western Algeria) in the context of the restoration. Acta scientifica naturalis, $7:$ 68-78. https://doi.org/10.2478/asn-2020-0022

Aouadj S.A., Nasrallah Y., Hasnaoui O. \& Khatir H., 2020. Impact of ecological restoration techniques on the dynamics of degraded ecosystems of the mounts of Saida: Case of the forests of Doui Thabet (West Algeria). Acta scientifica naturalis, 7: 68-77.

Aouadj S.A., Nasrallah Y., Hasnaoui O. \& Khatir H., 2020. Rare, endemic and threatned flora of the mounts of Saida (western of Algeria). Agrobiologia, 11: 45-57.

B.N.E.D.E.R., 1992. Etude du développement agricole dans la wilaya de Tlemcen. Rapport final et documents annexes, $297 \mathrm{pp}$.

Babali B., 2014. Contribution à une étude phytoécologique des monts de Moutas (Tlemcen- Algérie occidentale): aspects syntaxonomique, biogéographique et dynamique. Thése Doctorat Université de Tlemcen, 160 pp.

Benabdeli K., 1983. Mise au point d'une méthodologie d'appréciation de l'action anthropozoogène sur la végétation dans le massif forestier de Télagh (Algérie occidentale). Thèse de Doctorat. Development of amethodology for assessing the action anthropozoogène on vegetation in the forest of Telagh (western), $300 \mathrm{pp}$.

Benabdeli K., 1996. Aspects physionomico-structuraux et dynamiques des écosystèmes forestiers face à la pression anthropozoogène dans les monts de Tlemcen et les monts de Dhaya (Algérie septentrionale occidentale). Thèse de Doctorat d'État, Physionomico-structural Aspects and dynamic forest ecosystems under the pressure anthropozoogène in the mountains of Tlemcen and the mountains of Dhaya (North West Algeria). Ph. D thesis, University of Sidi Bel Abbes, Algeria, 356 pp.

Chabane A., 1982. Les pelouses naturelles de khroumirie (Tunisie): typologie et production de biomasse. Thèse présentée à la Faculté des Sciences et Techniques St. Jerome (Université d'Aix-Marseille, France).

D.S.A., 2019. Bilan technique et statistique annuel du secteur 2019, $10 \mathrm{pp}$.

Durand J.H., 1954. Les sols d'Algérie. S.E.S. Alger, 243 pp.
El Hamroun A., 1992. La végétation forestière, préforestière et présteppique de la Tunisie. Thèse de doctorat d'Etat es - Science Naturelle. Faculté des Sciences et Techniques de Saint Jérôme de l'Université Aix-Marseille France, 100 pp.

El Hamrouni A., 1978. Etude phytosociologique et problèmes d'utilisation et d'aménagement dans les forêts de pin d'Alep de la région de Kasserine. Thèse Doctorat Ingénierie Faculté des Sciences et Techniques de Saint-Jérôme, Université Aix-Marseille III, 106 pp.

Kadik B., 1987. Contribution à l'étude du pin d'Alep (Pinus halepensis) en Algérie. Ecologie, Dendrométrie, Morphologie. O.P.U. Alger.

Kunholtz-Lordat G., 1938. La terre incendiée. Essai d'agronomie comparée. Ed. Maison carrée. Nîmes, $361 \mathrm{pp}$.

Laaribya S., Alaoui A., Gmira N. \& Nassim G., 2012. Contribution à l'évaluation de la pression pastorale dans la forêt de la Maamora. Parcours forestiers et surpâturage. Nature \& Technologie, 1: 31-50.

Le Houerou H.N., 1971. Classification écoclimatique des zones arides (S.I) de l'Afrique du Nord. Ecologia mediterranea, 15, C.E.F.E., C.N.R.S-C.E.P.E Louis Emberger; Montpellier (France), pp. 95-136.

Le Houerou H.N., 1969. La végétation de la Tunisie steppique. Thèse de Doctorat Espaces Cultures Sociétés Aix Marseille III, 182 pp.

Long G., 1960. Les terrains de parcours de plaine, de plateau et de basse montagne dans la région méditerranéenne. Fourrages, 4: 97-127.

Montoya J.M., 1983. Pastoralismo mediterraneo - Monografia, Icona, 25, Ministero de agricultura- Madrid.

Quezel P., 1985. Definition of the Mediterranean region and the origin of its flora. In: Gomez-Campo C. (Ed.), Plant conservation in the Mediterranean area. Junk, Dordrecht, pp. 9-24.

Quezel P., 1995. La flore du bassin méditerranéen, origine, mise en place, endémisme. Ecologia mediterranea, 21: 19-39.

R.G.P.H., 2019. Renssencement global des populations et des habitants, pp. 10-25.

S.A.T.E.C., 1976. Etude développement intégré de la daïra de Tlemcen. Rapport technique, 93 pp.

Sebei H., 2001. Evaluation de la biomasse arborée et arbustive dans une séquence de dégradation de la suberaie à cytie de Kroumirie (Tunisie)- Annales des Sciences Forestières, 58: 175-191.

Sespedes, J., 2014. Hiérarchisation des stress environnementaux influençant les vulnérabilités microbiennes du "continuum" phyllosphère-litière de Pistacia lentiscus. Thèse de master, Aix-Marseille Université, $39 \mathrm{pp}$.

Zamiti K., 1993. Le pastoralisme forestier. Cahiers CERES, Série Géographie. 8: 33-45. 